\title{
MEDIA PEMBELAJARAN FINAL LINE ASSEMBLY CONTACTOR TESYS D SIZE 1\&2 BERBASIS VIDEO
}

\author{
Henny Juliana \\ * Informatics Engineering, Batam State Polytechnic \\ ** Multimedia and Network Engineering, Batam State Polytechnic
}

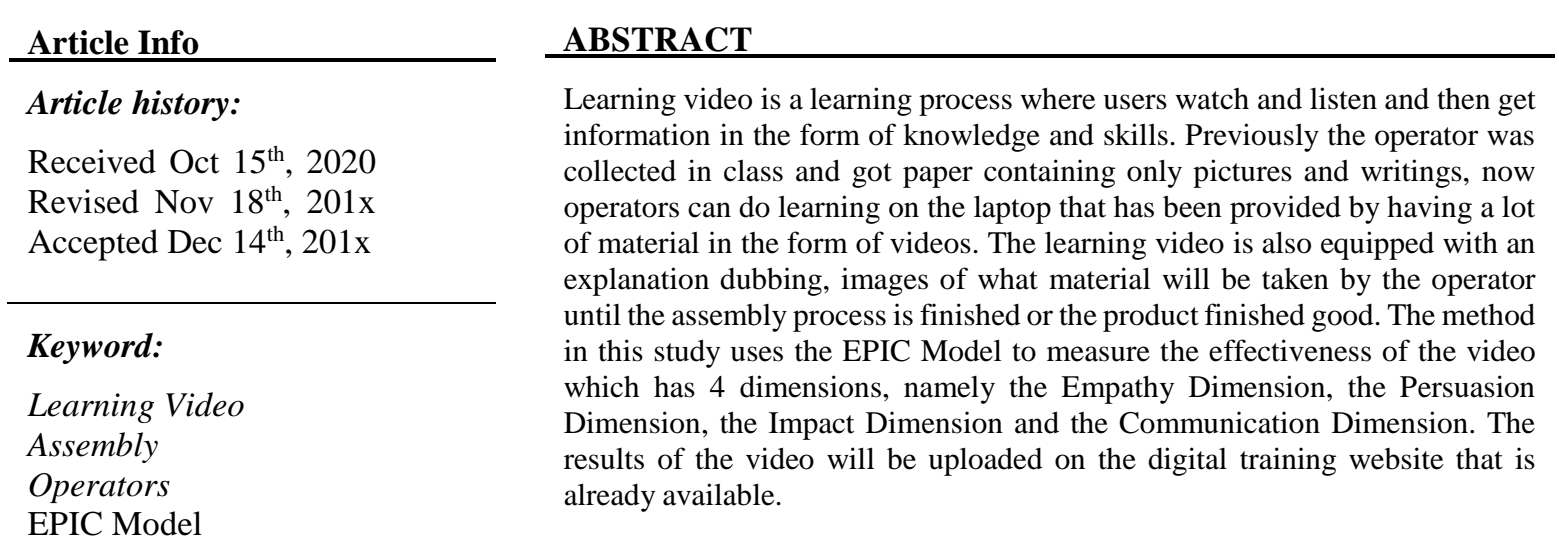

Copyright (C) 2020 Institute of Advanced Engineering and Science. All rights reserved.

\section{PENDAHULUAN}

Setiap bulannya PT. Schneider Electric Manufacturing Batam merekrut operator, setelah lolos selanjutnya operator melakukan training di dalam kelas. Butuh waktu 2 hari untuk lean game dan assessment. Trainer akan melakukan pekerjaan untuk membantu operator, melihat keterampilan dan kemampuan operator dan melihat prosedur pengoprasian di area line production. Biasanya jika operator ingin mempelajari cara melakukan assembly yang benar untuk menghasilkan sebuah produk finished good, digunakan dengan cara membaca kertas berisikan gambar/foto yang memiliki setiap tahapan proses atau biasa disebut dengan OWS (Operation Work Standars) dan JBS (Job Breakdown Sheet).

Akan tetapi dengan banyaknya materi production dan banyaknya operator yang bekerja, banyak juga sumber daya yang terbuang seperti tenaga, waktu dan uang. Oleh sebab itu, untuk mengembangkan sebuah media pembelajaran: yang tadinya sebuah kertas monoton berisikan gambar dan tulisan saja, akan dikembangkan menjadi sebuah media pembelajaran video. Adanya media pembelajaran yang berbasis video sekarang ini dapat meningkatkan efektifitas operator dalam pembelajaran serta dapat melatih skill operator dan memberikan pengetahuan terhadap operator baru.

Dulunya operator dikumpulkan dan pembelajaran juga dilakukan di kelas. Pada tahun 2019 dibuatlah satu tempat yang berada di lantai 3 PEM (Plant Electro Mechanic) bagi operator untuk mengisi waktu luang apabila mesin sedang breakdown atau pada jam istirahat, biasanya disebut digital learning corner. Sekarang operator bisa melakukan pembelajaran di laptop yang sudah disediakan yang memiliki banyak materi proses assembly dalam bentuk video, video pembelajaran yang dibuat hanya di upload di website dan hanya bisa di akses oleh karyawan PT. Schneider Electric Manufacturing Batam. Video pembelajaran tersebut juga dilengkapi dengan penjelasan dubbing (suara), gambar dari 
material apa saja yang akan diambil oleh operator sampai proses assembly selesai atau produk finished good.

Pada akhirnya akan merancang sebuah media pembelajaran Assembly Contactor Tesys D Size $1 \& 2$ ke dalam bentuk video untuk dapat menjadi peluang kinerja dari operator agar produk yang dihasilkan bagus dan mengurangi reject pada produk. Pengembangan rancangan media pembelajaran ini menggunakan metode pengembangan Luther Sutopo karena modelnya yang sistematis sehingga pekerjaan dapat dirangkai secara berurutan dalam upaya pemecahan masalah[1]. Hingga pada akhir dari perancangan ini penulis akan melakukan analisis efektivitas terhadap video pembelajaran yang telah dibuat dengan menggunakan metode EPIC (Empathy, Persuasion, Impact and Communications) untuk mengukur keefektifan produk video yang telah digunakan[2].

\section{LANDASAN TEORI}

\section{A. Media Video Pembelajaran}

Video merupakan salah satu jenis media audiovisual dan dapat menggambarkan suatu objek yang bergerak bersama-sama dengan suara alamiah atau suara yang sesuai. Video menyajikan informasi, memaparkan proses, menjelaskan konsep yang rumit, mengajarkan keterampilan, menyingkat atau memperpanjang waktu, dan mempengaruhi sikap[3].

\section{B. Manfaat Penggunaan Media Video dalam Pembelajaran}

Dengan video dapat menyaksikan suatu peristiwa yang tidak bisa disaksikan secara langsung, berbahaya, maupun peristiwa lampau yang tidak bisa dibawa langsung ke dalam kelas. Dapat memutar kembali video tersebut sesuai kebutuhan dan keperluan mereka. Pembelajaran dengan media video menumbuhkan minat serta memotivasi untuk selalu memperhatikan pelajaran[4].

\section{Perakitan (Assembly)}

Menurut Ibu Lasman Siahaan selaku Trainer Leader di PEM (Plant Electro Mechanic), Assembly merupakan proses merakit dari 1, 2, 3 atau 4 komponen menjadi satu sub assembly atau menjadi yang namanya finished good. Biasanya dalam satu cell akan menghasilkan sub assembly, tapi jika kita assembly dari sub assembly di line production manapun itu akan menjadikan finished good jadi intinya assembly itu adalah melakukan proses perakitan yang memilki banyak tahapan.
D. Assembly Contactor Tesys D Size 1\&2

Menurut Bapak Andry Anugrah Iskak selaku Method Engineer di PT. Schneider Electric Manufacturing Batam. Proses Assembly Contactor Tesys D Size $1 \& 2$ merupakan gabungan dari beberapa proses yang akan dirakit menjadi sebuah product final yang bernama "Contactor".

\section{E. Digital Training}

Digital training merupakan aplikasi berbasis web yang sudah disediakan oleh PT. Schneider Electric Manufacturing Batam berfungsi sebagai pembelajaran operator yang berisikan content video assembly, dari awal proses produk dirakit sampai menjadi produk finished good.

\section{F. Perangkat Lunak}

\section{Adobe Illustrator CS6}

Software ini digunakan untuk membuat desain atau gambar material ke dalam bentuk vektor. Desain tersebut seperti background dan beberapa komponen[5].

\section{Adobe Photoshop CS6}

Software ini gunakan untuk mengedit gambar dengan tool yaitu quick selection tool, berfungsi untuk membuang background dari gambar material dan crop gambar[6].

\section{Adobe After Effect CS6}

Software ini digunakan untuk membuat pergerakan gambar dan memberikan visual effect pada tulisan dan objek yang digunakan dalam video[7].

\section{Adobe Premier Pro CS6}

Software ini digunakan untuk membuat penyuntingan dalam pengolahan video. Aplikasi ini juga berfungsi untuk merangkai gambar, video dan audio[8].

\section{G. Alat yang Digunakan}

\section{Camcorder Sony HXR-NX100 Full HD} NXCAM Full HD

Untuk mendapatkan hasil yang memuaskan dalam merekam video pembelajaran Contactor Tesys D Size $1 \& 2$ menggunakan Camcorder Sony HXR-NX100 Full HD.

2. Tripod Manfrotto 502AH Video Head \& 475B Pro Tripod Kit

Dibutuhkan tripod pada saat pengambilan video, untuk mengurangi kelelahan dan menjaga keseimbangan camera agar tidak shake.

3. Sony UWP-D11 Camera-Mount Wireless Omni Lavalier Microphone System (UC14: 470 to $542 \mathrm{MHz}$ )

Pada saat mendubbing audio untuk video pembelajaran suara yang dihasilkan harus jelas dan tidak ada noise. 


\section{H. Metode Luther-Sutopo}

Menurut Luther metodologi pengembangan multimedia terdiri dari 6 tahap yaitu concept (pengonsepan), design (perancangan), material collecting (pengumpulan materi), assembly (pembuatan), testing (pengujian), dan distribution (pendistribusian) [1].

\section{Concept}

Tahap konsep dibutuhkan dalam produk agar dapat tersusun dengan baik. Di dalam tahap ini, tujuan dan hasil akhir produk berpengaruh kepada target.

\section{Design}

Menentukan tipografi tulisan, penggunaan warna dan storyboard pada video Assembly Contactor Tesys D Size 1\&2.

\section{Material Collection}

Pada tahap ini dilakukan pengumpulan bahan ajar yang akan disajikan dalam video pembelajaran. Bahan-bahan tersebut berupa materi video, gambar, audio, teks dan lain sebagainya.

\section{Assembly}

Tahap ini merupakan tahap pembuatan produk sesuai dengan konsep dan rancangan yang telah dibuat. Mulai dari bahan yang diperlukan, kemudian diolah dengan perangkat lunak yang dipakai.

\section{Testing}

Pada tahap ini, produk yang telah siap diuji kembali. Ada 2 tahap, yaitu alpha testing dan beta testing.

\section{Distribution}

Pada tahap ini, video akan diupload dalam website PT. Schneider Electric Manufacturing Batam yaitu "Digital Training".

\section{Metode Analisis Data EPIC}

Sebuah produk dapat diukur keefektifannya dengan menggunakan model EPIC (Durianto, 2003). Pengembangan model EPIC ini dilakukan oleh perusahaan peneliti pemasaran yaitu AC Nielsen. Ada 4 dimensi dalam model EPIC, yaitu:

\section{Dimensi Empati (Empaty)}

Pada dimensi empati ini menginformasikan apakah konsumen menyukai video tersebut dan adakah hubungan pribadi konsumen dengan video yang ada.

\section{Dimensi Persuasi (Persuasion)}

Dimensi ini menginformasikan bagaimana video yang dibuat dapat menguatkan produk.

\section{Dimensi Dampak (Impact)}

Dimensi dampak adalah hasil dari video yang dibuat apakah produk dapat lebih menonjol dibanding dengan produk lainnya.

\section{Dimensi Komunikasi (Communication)}

Dimensi Komunikasi memberikan informasi terhadap bagaimana konsumen memiliki kemampuan dalam mengingat pesan utama.

\section{J. Skala Likert}

Skala Likert merupakan teknik pengukuran sikap dimana subjek diminta untuk mengindikasi tingkat kesetujuan atau ketidaksetujuan terhadap masing-masing pertanyaan atau peryataan[9].

"Skala Likert digunakan untuk mengukur sikap, pendapat dan persepsi seseorang atau sekelompok orang tentang fenomena sosial"[10].

\section{Tabel 1 Metode skoring skala likert}

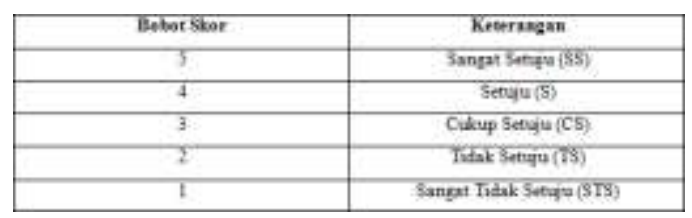

\section{ANALISIS DAN PERANCANGAN}

Dalam penelitian ini terbagi menjadi 3 tahapan, yaitu concept, design, material collecting dan proses analisis EPIC Model.

\section{A. Concept Video Pembelajaran}

Pembuatan video pembelajaran ini dilakukan dengan menggabungkan beberapa hasil dari pengambilan take shoot video menggunakan kamera secara langsung.

\section{B. Design Video Pembelajaran}

Pada tahap desain atau perancangan akan menampilkan tipografi tulisan, penggunaan warna, dan storyboard yang akan memperjelas setiap scene dari video pembelajaran "Assembly Contactor Tesys D Size 1\&2”.

\section{Tipografi}

Tipografi pada video pembelajaran "Assembly Contactor Tesys D Size 1\&2" menggunakan font Microsoft PhagsPa dan Bebas Neue untuk semua teks yang ada didalamnya.

\section{Penggunaan Warna}

Pada video pembelajaran ini akan digunakan warna-warna yang terang dengan tujuan untuk memperjelas video

\section{Storyboard}

Storyboard video pembelajaran "Assembly Contactor Tesys D Size 1\&2" memberikan penjelasan dan gambaran lengkap mengenai 
tiap scene yang akan ditampilkan pada video.

Tabel 2. Penggalan Storyboard (Dok. Pribadi, 2020)

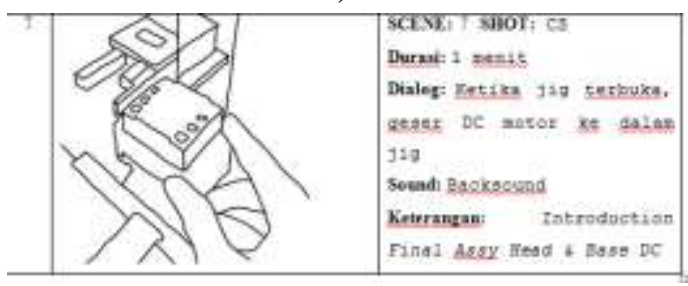

\section{Material Collecting}

Pada tahap ini merupakan tahap yang bertujuan untuk mengumpulkan bahan yang dibutuhkan dalam pembuatan video pembelajaran yaitu:sound effect, dan background music.

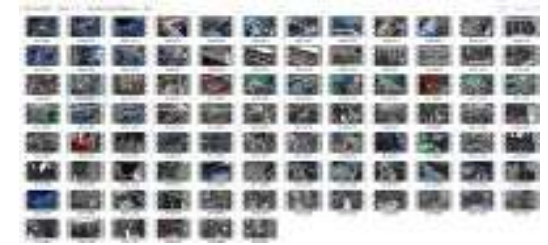

Gambar 1 Pengambilan Video Proses

\section{Pengukuran Analisis EPIC Model}

Sebuah video dapat diukur pengaruh efektivitasnya dari aspek komunikasi ataupun dampak yang dihasilkan oleh video tersebut, seperti potensi dampak kesadaran, pengetahuan, dan juga preferensi. Dalam penentuan jumlah responden, penulis akan menyebar kuesioner kepada 30 responden. Adapun pengukuran efektivitas ini menggunakan rumus-rumus melalui beberapa tahap[11].

\section{Analisa Sederhana}

Tahap pertama dalam mengukur efektivitas ini adalah dengan cara mendapatkan nilai presentase dari setiap jawaban masing-masing pernyataan dengan rumus: (1)

$$
-x 100 \%
$$

Keterangan:

$\mathrm{P}$ : Persentase

$J i$ : Jumlah responden yang memilih kategori tertentu

$J$ : Banyaknya jumlah responden

\section{Rata-rata Nilai Per-Dimensi}

Tiap jawaban diberikan bobot nilai sesuai jenis jawaban. Kemudian, setiap hasil jawaban dikalikan dengan masing-masing bobot yang diberikan, dan setelah mendapat hasil kalinya, seluruhnya hasil kali dijumlah dan dibagi sesuai dengan total frekuensi pertanyaan per dimensi, dengan rumus: (2)

\section{Keterangan: \\ R : Rata-rata bobot \\ $f \quad$ : Frekuensi \\ $w$ : Bobot}

Untuk menentukan posisi tanggapan dari hasil jawaban responden dengan nilai tiap pertanyaan, maka digunakan rentang skala penilaian, dengan rumus: (3)

\section{Keterangan: \\ R(bobot) : bobot tersebar-bobot terkecil M : banyaknya kategori bobot}

Rentang skala yang digunakan adalah rentang skala Likert dari 1 hingga 5, maka rentang nilai yang didapat adalah:

Maka didapatkan posisi hasil keputusan penilaian jawaban menjadi:

Gambar 2 Skala keputusan (sumber:Shoreana, 2015)

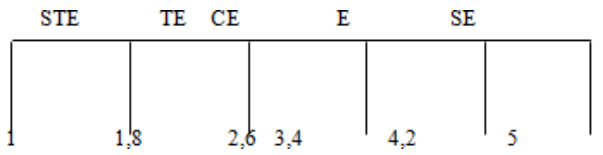

Tabel 3 Skala penilaian EPIC

\begin{tabular}{|c|c|}
\hline Interval & Kateauri \\
\hline $1-1,8$ & Sangat Tiaks Efaktif (STE) \\
\hline $1,81-2,6$ & That Erekaif (TE) \\
\hline $2,61-3,4$ & Cokup Lfentef (CE) \\
\hline $3,41=4,1$ & Extar (E) \\
\hline $421-5$ & Samgat If fantif (SE) \\
\hline
\end{tabular}

\section{EPIC Rate}

Tahap terakhir adalah penentuan EPIC rate yang diperoleh dari data rata-rata per-dimensi. Hasil dari setiap dimensi EPIC dirata-ratakan menjadi EPIC rate, dengan rumus:

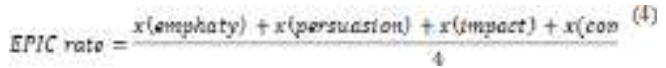

\section{Keterangan:}

$x$ (empathy) : Hasil rata-rata bobot empati $x$ (persuasion) : Hasil rata-rata bobot persuasi $x$ (impact) : Hasil rata-rata bobot dampak $x$ (communication):Hasil rata-rata bobot komunikasi 


\section{Rancangan Kuesioner}

Tabel 4 Rancangan Kuesioner

\begin{tabular}{|c|c|c|}
\hline \multicolumn{2}{|c|}{ SamXESAD } & \\
\hline \multicolumn{2}{|r|}{ tsin } & \\
\hline \multicolumn{2}{|r|}{ Liat } & \\
\hline Si & Dimeas & Roncanan Perdeatass \\
\hline \multirow{3}{*}{1} & \multirow{3}{*}{ 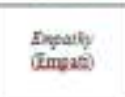 } & 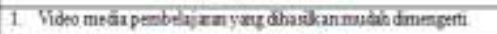 \\
\hline & & 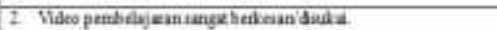 \\
\hline & & 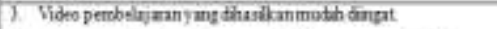 \\
\hline \multirow{3}{*}{2} & \multirow{3}{*}{ Penuaritar } & 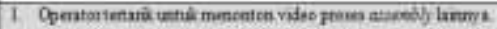 \\
\hline & & 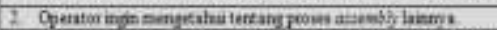 \\
\hline & & 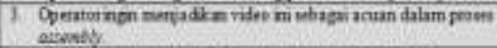 \\
\hline \multirow{3}{*}{3} & \multirow{3}{*}{$\begin{array}{l}\text { Tyeort } \\
\text { (Dangex) }\end{array}$} & 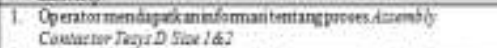 \\
\hline & & 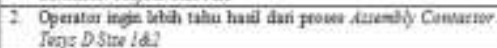 \\
\hline & & 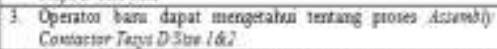 \\
\hline \multirow[t]{3}{*}{4} & \multirow{3}{*}{ 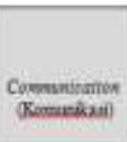 } & 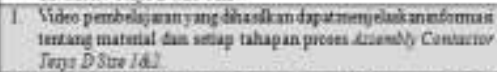 \\
\hline & & 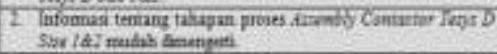 \\
\hline & & 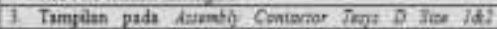 \\
\hline
\end{tabular}

\section{HASIL DAN PEMBAHASAN}

Hasil implementasi rancangan berdasarkan metode penelitian Luther Sutopo yaitu assembly, testing, dan distribution.

\section{A. Assembly}

Pengolahan seluruh data yang telah dikumpulkan kemudian diolah menggunakan perangkat lunak. Beberapa tahap yang dilakukan pada proses assembly ini adalah mengedit gambar material, editing, dubbing dan rendering.

\section{Pengunaan Tipografi}

Tipografi pada teks safety, quality dan process menggunakan software dari Adobe Premier.

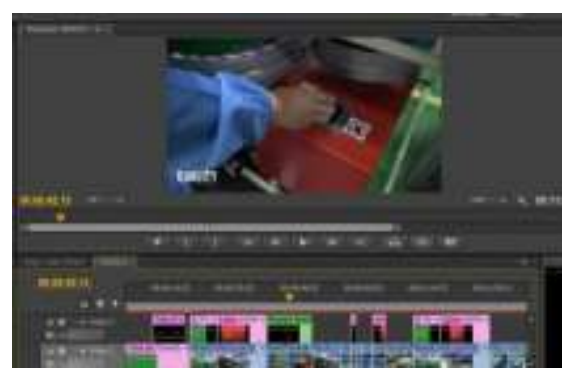

Gambar 3 Penerapan Tipografi

\section{B. Editing}

Proses editing yang dilakukan adalah pada bagian audio dan video. Kedua proses ini dijelaskan sebagai berikut:

\section{Video Editing}

Tahap ini adalah memilih video mentah yang telah didapatkan melalui perekeman menggunakan kamera ke dalam workspace Adobe Premiere Pro CS6.

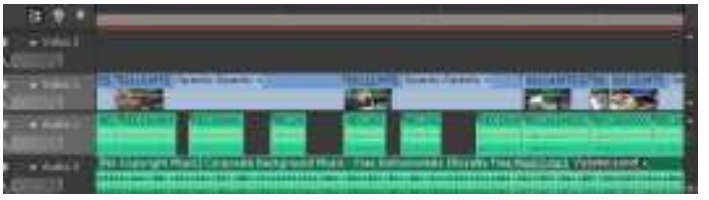

Gambar 4 Penyusunan Video Assembly Contactor Tesys D Size $1 \&^{1}$

\section{Audio Editing}

Selanjutnya adalah proses dubbing (merekam suara) dengan menggunakan smartphone.

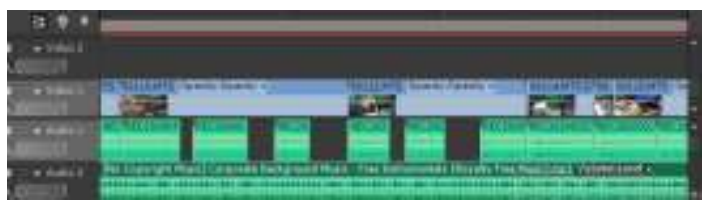

Gambar 5 Penyesuaian Audio Dubbing

\section{Backsound Editing}

Video memiliki latar musik yang didapatkan secara gratis melalui internet. Musik ini digunakan sebagai backsound utama pada video yang dibuat.

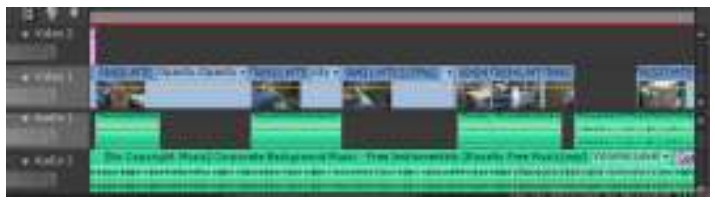

Gambar 6 Penyesuaian Durasi Backsound

\section{Sound Effects}

Kemudian pada tahap ini, backcsound dan video yang telah disusun, ditambahkan dengan sound effects.

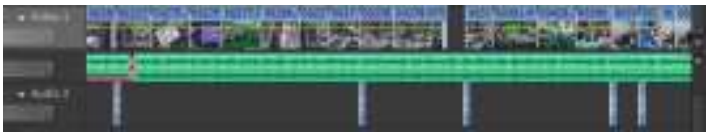

Gambar 7 Penyesuaian Sound Effects

\section{Pop Up Foto Material}

Pada tahap ini, semua material Assembly Contactor Tesys D Size 1\&2 dengan format jpg akan sebagai pop up untuk memperjelas detail isi konten pada video.

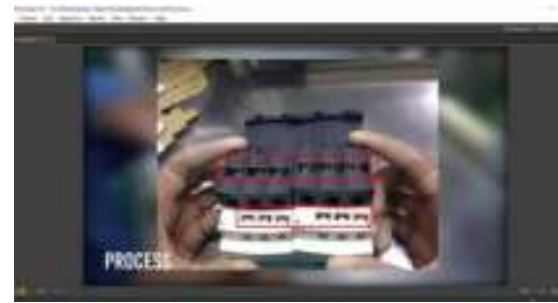

Gambar 8 Pop Up Gambar Video 


\section{Video Rendering}

At this last stage, the results of all the merging and editing that has been done are arranged in accordance with the storyboard, then rendering will be done.

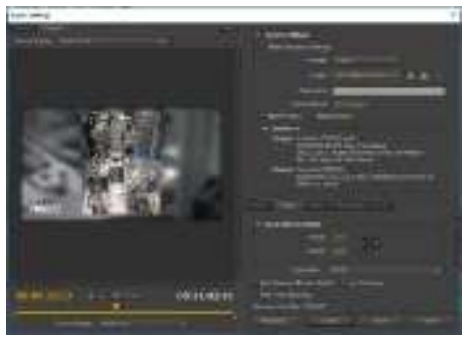

\section{Gambar 9 Rendering Akhir Keseluruhan}

\section{Testing}

Pada tahap ini kegiatan yang dilakukan yaitu menguji video media pembelajaran yang telah diproduksi.

\section{Pengujian Kesesuaian Storyboard dengan} Produk

Telah dilakukan pengujian terhadap hasil implementasi yaitu menguji kesesuaian antara rancangan dengan produk yang dihasilkan.

Tabel 5 Hasil Implementasi Storyboard
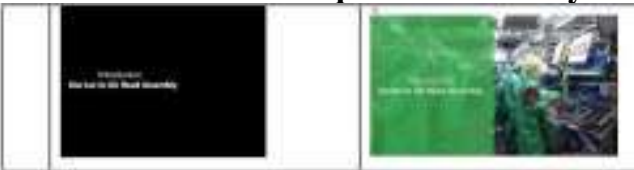

\section{Uji Pemutaran Video}

Dalam pengujian ini bertujuan untuk mengetahui apakah produk yang dihasilkan dapat diputar melalui media player yang umum digunakan.

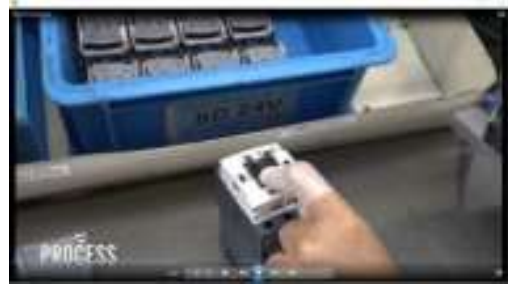

Gambar 10 Hasil Pemutaran Video

\section{Uji Coba Alpha}

Uji coba alpha merupakan tahap uji coba yang dilakukan oleh ahli media dan ahli materi. Dalam melaksanakan tahapan ini, dilakukan uji oleh ahli materi yang berupa validasi mengenai konten Assembly Contactor Tesys D untuk memastikan kesesuaian materi yang disajikan.

\section{Uji Coba Beta}

Pengujian ini dilakukan selama 7 hari lamanya. Jumlah responden yang mengisi kuesioner ada sebanyak 30 orang dengan spesifikasi responden berdasarkan usia antara 19 sampai 27 tahun dan pekerjaan responden adalah operator line di PT.Schneider Electric Manufacturing Batam.

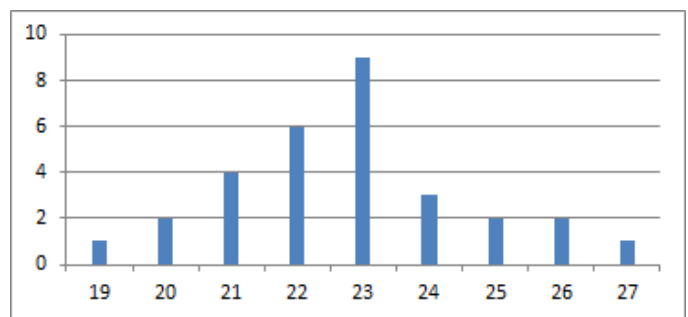

Gambar 11 Responden berdasarkan usia

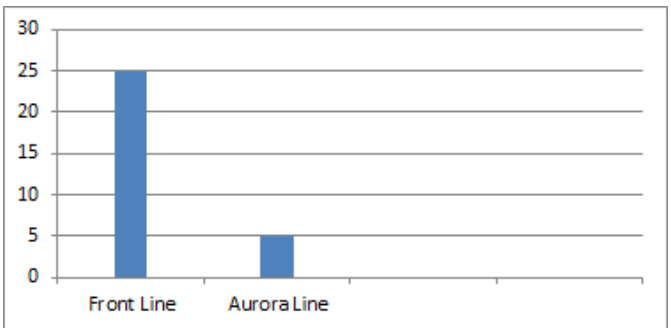

Gambar 12 Responden berdasarkan posisi line

Grafik dari gambar 11 dan gambar 12 menunjukkan bahwa distribusi responden berdasarkan usia paling banyak berada pada rentang usia 23 tahun dan berdasarkan posisi line paling banyak adalah front line.

\section{Analisis Efektivitas Iklan Video}

Selanjutnya dilakukan analisis efektivitas produk (video pembelajaran) menggunakan model EPIC menggunakan 4 parameter yaitu empati, persuasi, dampak, dan komunikasi.

Tabel 6 Hasil Pengelahan Data Responden

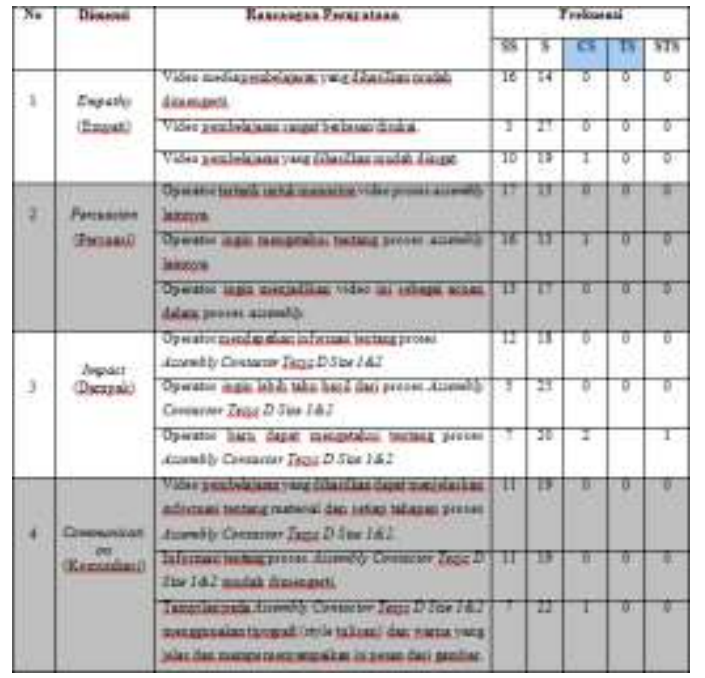




\section{Analisis Dimensi Empathy (Empati)}

Dimensi empati diberikan 3 pernyataan seputar tentang kesukaan audience terhadap video yang dibuat. Pernyataan empati pertama dan seterusnya disimbolkan dengan E1, E2, dan E3.

E1: diperoleh bahwa terdapat 2 skala yang diisi oleh audience, yaitu skala Sangat Setuju (SS) dengan presentase $5.3 \%$ (16 orang) dan Setuju (S) dengan presentase $4.7 \%$ (14 orang).

E2: diperoleh bahwa terdapat 2 skala yang diisi oleh audience, yaitu skala Sangat Setuju (SS) dengan presentase $1.0 \%$ (3 orang) dan Setuju (S) dengan presentase $9.0 \%$ (27 orang).

E3: diperoleh bahwa terdapat 3 skala yang diisi oleh audience, yaitu skala Sangat Setuju (SS) dengan presentase 3.3\% (10 orang), Setuju (S) dengan presentase $6.3 \%$ (19 orang), Cukup Setuju (CS) dengan presentase $0.3 \%$ (1 orang).

Dengan persentase yang disebutkan, maka hasil rata-rata dimensi empati keseluruhan diperoleh sebesar 4.31 menunjukkan bahwa dimensi ini termasuk dalam kategori sangat efektif (SE).

\section{Analisis Dimensi Persuasion (Persuasi)}

Dimensi persuasi diberikan 3 pernyataan seputar tentang informasi pada video sehingga audience tertarik pada produk. Pernyataan persuasi pertama dan seterusnya disimbolkan dengan P1, P2, dan P3.

P1: diperoleh bahwa terdapat 2 skala yang diisi oleh audience, yaitu skala Sangat Setuju (SS) dengan presentase 5.6\% (17 orang) dan Setuju (S) dengan presentase $4.3 \%$ (13 orang).

P2: diperoleh bahwa terdapat 3 skala yang diisi oleh audience, yaitu skala Sangat Setuju (SS) dengan presentase 5.6\% (16 orang), Setuju (S) dengan presentase $4.3 \%$ (13 orang) dan Cukup Setuju (CS) dengan presentase $0.3 \%$ (1 orang).

P3: diperoleh bahwa terdapat 2 skala yang diisi oleh audience, yaitu skala Sangat Setuju (SS) dengan presentase $4.3 \%$ (13 orang), Setuju (S) dengan presentase $5.6 \%$ (17 orang).

Dengan persentase yang disebutkan, maka hasil rata-rata dimensi peruasi keseluruhan diperoleh sebesar 4.36 menunjukkan bahwa dimensi ini termasuk dalam kategori sangat efektif (SE).

\section{Analisis Dimensi Impact (Dampak)}

Dimensi dampak diberikan 3 pernyataan seputar tentang keterlibatan audience dalam informasi yang disampaikan pada video yang dibuat. Pernyataan dampak pertama dan seterusnya disimbolkan dengan I1, I2, dan I3.
I1: diperoleh bahwa terdapat 2 skala yang diisi oleh audience, yaitu skala Sangat Setuju (SS) dengan presentase $4.0 \%$ (12 orang) dan Setuju (S) dengan presentase $6.0 \%$ (18 orang).

I2: diperoleh bahwa terdapat 2 skala yang diisi oleh audience, yaitu skala Sangat Setuju (SS) dengan presentase $1.6 \%$ (5 orang) dan Setuju (S) dengan presentase $8.3 \%$ (25 orang).

I3: diperoleh bahwa terdapat 4 skala yang diisi oleh audience, yaitu skala Sangat Setuju (SS) dengan presentase $2.3 \%$ (7 orang), Setuju (S) dengan presentase $6.6 \%$ (20 orang), Cukup Setuju (CS) dengan presentase $0.6 \%$ (2 orang), dan Sangat Tidak Setuju (STS) dengan presentase $0.3 \%$ (1 orang)

Dengan persentase yang disebutkan, maka hasil rata-rata dimensi dampak keseluruhan diperoleh sebesar 4.20 menunjukkan bahwa dimensi ini termasuk dalam kategori efektif (E).

\section{Analisis Dimensi Communication (Komunikasi) \\ Dimensi komunikasi diberikan 3 pernyataan} seputar tentang bagaimana kekuatan video dalam penyampaian informasi kepada audience. Pernyataan komunikasi pertama dan seterusnya disimbolkan dengan $\mathrm{C} 1, \mathrm{C} 2$, dan $\mathrm{C} 3$.

C1: diperoleh bahwa terdapat 2 skala yang diisi oleh audience, yaitu skala Sangat Setuju (SS) dengan presentase 3.6\% (11 orang) dan Setuju (S) dengan presentase 6.3\% (19 orang).

C2: diperoleh bahwa terdapat 2 skala yang diisi oleh audience, yaitu skala Sangat Setuju (SS) dengan presentase 3.6\% (11 orang) dan Setuju (S) dengan presentase 6.3\% (19 orang),

C3: diperoleh bahwa terdapat 3 skala yang diisi oleh audience, yaitu skala Sangat Setuju (SS) dengan presentase $2.3 \%$ (7 orang), Setuju (S) dengan presentase $7.3 \%$ (22 orang), dan Cukup Setuju (CS) dengan presentase $0.3 \%$ (1 orang).

Dengan persentase yang disebutkan, maka hasil rata-rata dimensi komunikasi keseluruhan diperoleh sebesar 4.30 menunjukkan bahwa dimensi ini termasuk dalam kategori sangat efektif (SE).

Tahap EPIC rate merupakan proses perhitungan terakhir setelah setiap dimensi didapatkan nilai rata-ratanya. 


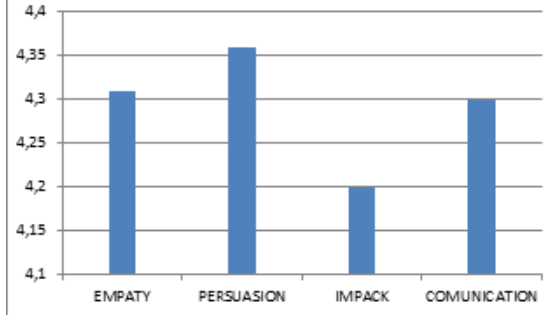

Gambar 13 Grafik rata-rata Per-Dimensi

Dan hasil kategori dari setiap dimensi EPIC dapat dilihat pada tabel 4.3 berikut ini

\section{Tabel 7 Kategori dimensi EPIC}

\begin{tabular}{|c|c|c|}
\hline Parameter & Rata-rata & Kategori \\
\hline Empathy & 4.31 & Sangat Efektif \\
\hline Persuasion & 4.36 & Sangat Efektif \\
\hline Impact & 4.20 & Efektif \\
\hline Communication & 4.30 & Sangat Efektif \\
\hline
\end{tabular}

Dimensi persuasi memiliki nilai paling tinggi diantara dimensi lainnya yang memiliki nilai 4.36 (sangat efektif) dan dimensi dampak memiliki nilai paling rendah diantar dimensi lainnya yang memiliki nilai 4.20 (efektif).

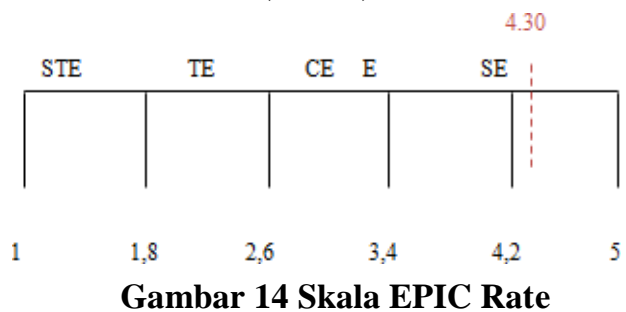

Dari gambar 14, hasil EPIC rate yang didapat untuk keseluruhan dimensi adalah 4.30, dimana angka ini masuk kedalam kategori sangat efektif (SE).

\section{E. Distribution}

Pada tahap ini kegiatan yang dilakukan yaitu menyimpan video pembelajaan yang telah diproduksi dalam media penyimpanan yang sudah di upload, yaitu digital training link:

10.155.152.114/digital\%20training

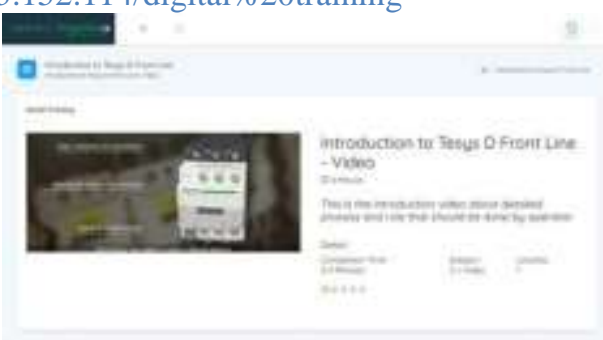

\section{Gambar 15 Dasboard Video Assembly Tesys $D$ Front Line}

\section{KESIMPULAN}

Perancangan dan pembuatan video pembelajaran pada Final Line Assembly Contactor Tesys D berhasil dilakukan dengan menggunakan metode Luther Sutopo dab analisis efektivitas video menggunaka EPIC Model. Video yang dihasilkan dalam format .mp4 dengan durasi 11 menit memuat tentang informasi penjelasan produk sampai pada tahap finished good dan di upload di web digital learning.

Berdasarkan hasil EPIC rate mencapai nilai 4.30, artinya produk yang dihasilkan sangat efektif(SE) digunakan sebagai media pembelajaran berbasis video pada materi Final Line Assembly Contactor Tesys D Size $1 \& 2$ di PT. Scheider Electric Manufacturing Batam. 


\section{DAFTAR PUSTAKA}

[1] Binanto, Iwan. 2010 : 259. Model Pengembangan Multimedia Versi Luther. Sumber : Iwan Binanto, 2010: 259

[2] Durianto, 2003, Inovasi Pasar dengan Iklan yang Efektif, Jakarta, Gramedia Pustaka Utama

[3] Arsyad, Azhar. 2011 : 49. Media Video Pembelajaran.

[4] Prastowo, Andi. 2012 : 302. Manfaat Penggunaan Media Video dalam Pembelajaran.

[5] Bayu, I Made. 2012. E-book Adobe Illustrator Chapter 1 Berbagai Sumber. Jakarta.

[6] Kuryanti 2015 : 203. “Adobe Photoshop Perangkat Lunak Editor Citra Buatan Adobe System.

[7] Hariyadi, Slamet. 2004. Membuat Effect Visual dengan Adobe After Effects 6x. Jakarta: PT Elex Media Komputindo.

[8] Wahana. 2010. Kolaborasi Adobe Premiere pro CS5 dan After Effect CS5. Semarang: ANDI

[9] Hendryadi. 2017. Validasi Isi: Tahap Awal Pengembangan Kusioner. Surabaya: Institut Teknologi Sepuluh Nopember (ITS)

[10] Sugiyono. 2013. Metode Penelitian Kuantitatif, Kualitatif dan R\&D. Bandung: Alfabeta.

[11] Shoreana, Thyeci. 2015. Analisis Efektivitas Iklan Televisi Sari Manggis Mastin Dengan Menggunakan Model AIDA dan EPIC, Skripsi. Bogor: Institut Pertanian 